\title{
Natural Variation in Grain Selenium Concentration of Wild Barley, Hordeum spontaneum, Populations from Israel
}

\author{
Jun Yan • Fang Wang • Haibo Qin • Guoxiong Chen • \\ Nevo Eviatar • Tzion Fahima • Jianping Cheng
}

Received: 17 April 2010 /Accepted: 1 July 2010 /

Published online: 21 July 2010

C The Author(s) 2010. This article is published with open access at Springerlink.com

\begin{abstract}
Wild barley (Hordeum spontaneum), the progenitor of cultivated barley, is an important genetic resource for cereal improvement. Selenium (Se) is an essential trace mineral for humans and animals with antioxidant, anticancer, antiarthropathy, and antiviral effects. In the current study, the grain Se concentration (GSeC) of $92 \mathrm{H}$. spontaneum genotypes collected from nine populations representing different habitats in Israel was investigated in the central area of Guizhou Province, China. Remarkable variations in $\mathrm{GSeC}$ were found between and within populations, ranging from 0 to $0.387 \mathrm{mg} \mathrm{kg}^{-1}$ among the 92 genotypes with an average of $0.047 \mathrm{mg} \mathrm{kg}^{-1}$. Genotype $20 \_$C from the Sede Boqer population had the highest GSeC, while genotype 25_1 from the Atlit population had the lowest. The mean value of $\mathrm{GSeC}$ in each population varied from 0.010 to $0.105 \mathrm{mg} \mathrm{kg}^{-1}$. The coefficient of variation for each population ranged from $12 \%$ to $163 \%$. Significant correlations were found between GSeC and 12 ecogeographical factors out of 14 studied. Habitat soil type also significantly affected GSeC. The wild barley exhibited wider GSeC ranges and greater diversity than its cultivated counterparts. The higher Se grain concentrations found in H. spontaneum populations suggest that wild barley germplasm confer higher abilities for Se uptake and
\end{abstract}

J. Yan $\cdot$ F. Wang $\cdot$ J. Cheng $(\triangle)$

Institute of Triticeae Crops, Guizhou University, Guiyang 550025, China

e-mail: chengjianping@gmail.com

J. Yan $\cdot$ N. Eviatar $\cdot$ T. Fahima

Institute of Evolution and the Department of Evolutionary and Environmental Biology,

Faculty of Natural Sciences, University of Haifa, Haifa 31905, Israel

H. Qin

State Key Laboratory of Environmental Geochemistry, Institute of Geochemistry,

Chinese Academy of Sciences, Guiyang 550002, China

G. Chen

Cold and Arid Regions Environmental and Engineering Research Institute,

Chinese Academy of Sciences, Lanzhou 730000, China 
accumulation, which can be used for genetic studies of barley nutritional value and for further improvement of domesticated cereals.

Keywords Ecogeographical factors - Grain selenium concentration · Hordeum spontaneum . Israel $\cdot$ Wild barley

\section{Introduction}

The essential trace mineral selenium (Se) is of fundamental importance to human and livestock health [1-3]. Se enters the food chain mainly through plants. In many countries, soils are often low in available Se; hence, the food systems are deficient in Se [4-6]. Based on surveys of plasma or serum Se levels, Combs [4] estimated that from half a billion to a billion people worldwide may suffer from Se deficiency.

Cereals, meat, and fish are the main sources of Se in most diets [4]. In foods, the Se exists in different chemical forms, with Se being generally more bioavailable from plants than from animal foodstuffs $[7,8]$. More than $80 \%$ of the total Se in seleniferous corn, wheat, and soybean consists of L-(1)-selenomethionine [9], which is the most appropriate supplemental form of Se in major staple foods [10]. As a main source of calorie intake, cereal-based foods are extensively consumed in the developing world [11]. However, cereals are inherently very poor in both concentration and bioavailability of microelements such as $\mathrm{Zn}, \mathrm{Fe}$, and $\mathrm{Se}$ in the seeds, particularly when grown in microelementdeficient soils $[8,11,12]$. Cereal crops such as wheat, barley, rye, and oats are non-Seaccumulators, rarely accumulating more than $0.1 \mathrm{mg} \mathrm{Se} \mathrm{kg}^{-1}$ dry weight [13]. Developing cereals that are genetically enriched in micronutrients and proteins and improving their bioavailability (biofortification) using genetics and genomics tools are considered as promising and cost-effective approaches to reducing malnutrition [6, 14-17]. Moreover, the existence of large genetic variation in grain micronutrients is essential for a successful breeding program aimed at the development of new micronutrient-rich plant genotypes.

Wild barley, Hordeum spontaneum C. Koch, is the progenitor of cultivated barley, Hordeum vulgare L. ssp. vulgare [18]. It is widely distributed throughout the eastern Mediterranean rim and western Asian countries [18]. The center of diversity for $H$. spontaneum and the primary site of its domestication are considered to be the Fertile Crescent of the Near East [18-20]. In Israel, H. spontaneum is abundant, occupying an extraordinarily large diversity of habitats ranging from the mesic Mediterranean to the xeric southern steppes [21]. Several decades of studies on genetic resources of wild cereals (wheat and barley) for crop improvement, conducted at the Institute of Evolution at the University of Haifa, Israel, have revealed that the vast genetic resources of wild cereals have great potential for improving the narrowing genetic base of domesticated cereals [18, 21-26]. Moreover, barley has a self-fertile, diploid $(2 n=2 x=14)$ genetic system and can therefore serve as a model species for genetic and physiological studies in Triticeae species [27]. In particular, barley cannot be grown in soil with excess Se without the risk of Se toxicity because it is a Se-sensitive plant [18]. Therefore, wild barley is an optimized model species for improving grain Se content in cereals via gene introgression. The objectives of the present study were to analyze the variation in grain Se concentration $(\mathrm{GSeC})$ in Israeli $H$. spontaneum populations and to choose a set of donor parents for the breeding of Seenriched barley cultivars. 


\section{Materials and Methods}

\section{Plant Materials}

Ninety-two genotypes from nine populations of the wild barley $H$. spontaneum, representing different geographical zones in Israel (Fig. 1 and Table 1), were used in the present study. All nine populations were selected from the Gene Bank Collection of the Institute of Evolution at the University of Haifa: six of them originated from mesic habitats in the north and center of Israel, with mean annual rainfall of $>500 \mathrm{~mm}$, Mt. Hermon

Fig. 1 Geographical location of Israeli Hordeum spontaneum populations used in the present study. 1, Mt. Hermon; 10, Maalot; 20, Sede Boqer; 22, Mehola; 24, Akhziv; 25, Atlit; 26, Caesarea; 32, Ein-Zukim; 37, "Evolution Canyon"

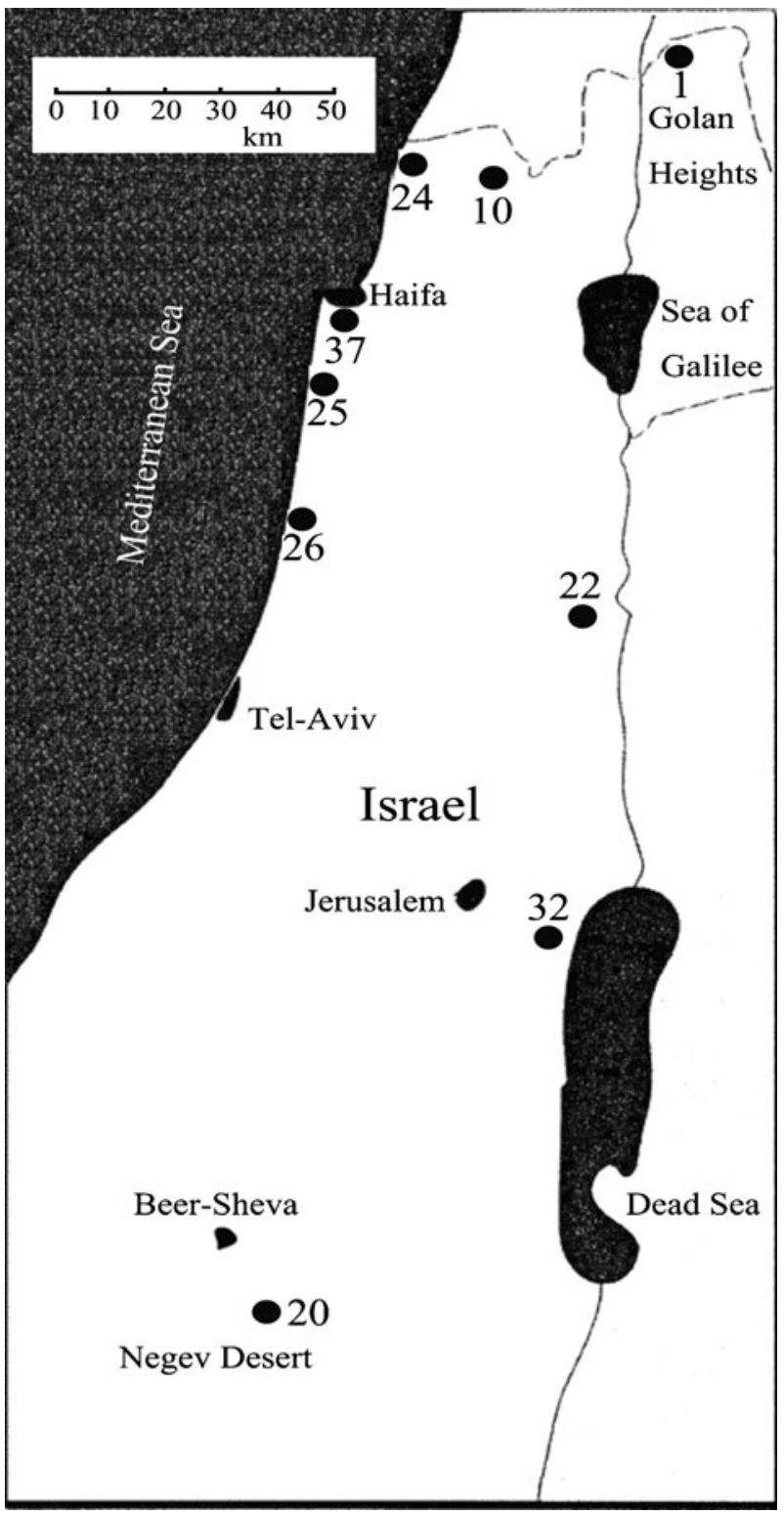


Table 1 Ecogeographical Factors of the Nine Hordeum spontaneum Populations in Israel

\begin{tabular}{llllllllllllllll}
\hline ID $^{\mathrm{a}}$ & Population & Ln & Lt & $\mathrm{Al}$ & $\mathrm{Tm}$ & $\mathrm{Ta}$ & $\mathrm{Tj}$ & $\mathrm{Td}$ & $\mathrm{Tdd}$ & $\mathrm{Ev}$ & $\mathrm{Rn}$ & $\mathrm{Rd}$ & Hu14 & Huan & So \\
\hline 1 & Mt. Hermon & 35.75 & 33.28 & 1,530 & 11 & 20 & 1 & 19 & 6 & 160 & 1,400 & 70 & 52 & 58 & 1 \\
10 & Maalot & 35.27 & 33.00 & 500 & 17 & 23 & 8 & 15 & 10 & 150 & 785 & 55 & 50 & 64 & 2 \\
20 & Sede Boqer & 34.78 & 30.87 & 450 & 19 & 26 & 9 & 15 & 13 & 168 & 91 & 15 & 36 & 53 & 6 \\
22 & Mehola & 35.48 & 32.13 & -150 & 22 & 30 & 13 & 17 & 13 & 180 & 270 & 39 & 34 & 53 & 3 \\
24 & Akhziv & 35.10 & 33.05 & 10 & 20 & 26 & 12 & 13 & 10 & 130 & 620 & 56 & 60 & 67 & 3 \\
25 & Atlit & 34.95 & 32.70 & 50 & 20 & 26 & 13 & 13 & 9 & 133 & 500 & 48 & 65 & 72 & 4 \\
26 & Caesarea & 34.90 & 32.50 & 10 & 20 & 26 & 13 & 13 & 9 & 130 & 540 & 48 & 65 & 72 & 4 \\
32 & Ein-Zukim & 35.44 & 31.74 & -200 & 24 & 31 & 15 & 16 & 12 & 210 & 100 & 20 & 35 & 52 & 6 \\
37 & Evolution Canyon & 34.58 & 32.43 & 90 & 22.5 & 28 & 13 & 15 & 9 & 142 & 600 & 48 & 65 & 67 & 1 \\
\hline
\end{tabular}

Geographical variables: $\mathrm{Ln}=$ longitude (decimal), $\mathrm{Lt}=$ latitude (decimal), and $\mathrm{Al}=$ altitude (meters). Temperature variables: Tm $=$ mean annual temperature $\left({ }^{\circ} \mathrm{C}\right), \mathrm{Ta}=$ mean August temperature $\left({ }^{\circ} \mathrm{C}\right), \mathrm{Tj}=\mathrm{mean}$ January temperature $\left({ }^{\circ} \mathrm{C}\right), \mathrm{Td}=$ mean seasonal temperature difference $\left({ }^{\circ} \mathrm{C}\right)$, $\mathrm{Tdd}=$ mean daily temperature difference $\left({ }^{\circ} \mathrm{C}\right)$, and $\mathrm{Ev}=$ mean annual evaporation. Water variables: $\mathrm{Rn}=$ mean annual rainfall (millimeters), $\mathrm{Rd}=$ mean number of rainy days, Hu14=mean humidity at 1400 hours (percent), Huan=mean annual humidity (percent), and $\mathrm{Dw}=$ mean number of dewy nights in summer (millimeters). Dummy soil variables: So=soil types, 1 terra rosa, 2 rendzina, 3 alluvium, 4 sandy loam, 6 loess (desert soil)

${ }^{a}$ Population IDs and selected environmental data are based on [21]; Ein-Zukim data is based on [63]

(population 1), Maalot (10), Akhziv (24), Atlit (25), Caesarea (26), and "Evolution Canyon" (37); and the other three were from xeric habitats in Israel's central and southern regions, with mean annual rainfall of $<300 \mathrm{~mm}$, Sede Boqer (20), Mehola (22), and EinZukim (near the Dead Sea; 32; Fig. 1 and Table 1). Ten barley cultivars from five provinces in China-Yangnongpi 5, Yancheng 01094, and Supi 4 from Jiangsu Province; Ganpi 3 from Gansu Province; Baoshan 8640-1, Yunpi 2, and Yunpi 6 from Yunnan Province; E32380 from Hubei Province; and Zhexiu 13 and Zhexiu 33 from Zhejiang Provincewere used as controls. All cultivars were provided by the Hangzhou National Barley Improvement Center in China.

A randomized complete block design with three replications was used. Seeds of the 92 wild barley genotypes and ten barley cultivars were sown in a field of loess soil under natural rainfall conditions at an experimental station in the central area of Guizhou Province, China (latitude $26^{\circ} 25^{\prime}$, longitude $106^{\circ} 40^{\prime}$, altitude $1,096 \mathrm{~m}$, mean annual rainfall $1,500 \mathrm{~mm}$, soil Se content $0.20 \mathrm{mg} \mathrm{kg}^{-1}$, and $\mathrm{pH}$ 6.6) in mid November 2006. Fully mature spikes were harvested manually from May to June 2007.

\section{Determination of Se in Barley Seeds}

The barley caryopses were dehulled by removing awn, glumes, lemma, and palea. Se concentration in the barley grains was determined by hydride generation-atomic fluorescence spectrometry (HG-AFS) following a modified protocol [28] at the State Key Laboratory of Environmental Geochemistry, Institute of Geochemistry, Chinese Academy of Sciences. The grains were washed thoroughly with deionized water, dried at $70^{\circ} \mathrm{C}$, pulverized, and passed through a 100 -mesh $(0.149 \mathrm{~mm})$ sieve. For digestion, $0.100 \mathrm{~g}$ of each sample was digested in a 50-mL PTFE tube with $3 \mathrm{~mL} \mathrm{HNO}_{3}$ (GR grade, Merck) at room temperature for $3 \mathrm{~h}$ and then at $145^{\circ} \mathrm{C}$ for $8 \mathrm{~h}$. After cooling to room temperature, the tube was opened, and $2 \mathrm{~mL}$ $\mathrm{H}_{2} \mathrm{O}_{2}$ (GR grade, Merck) was added. The mixture was evaporated to dryness at $70^{\circ} \mathrm{C}$. The dried mixture was redissolved in $3 \mathrm{~mL} 5 \mathrm{M} \mathrm{HCl}$ (ACS grade, Fisher Scientific) and transferred 
to a $25-\mathrm{mL}$ volumetric glass tube (Pyrex). The final solution was prepared by heating it at $90^{\circ} \mathrm{C}$ in a water bath for $90 \mathrm{~min}$ and then diluting it to $25 \mathrm{~mL}$ with deionized water.

An atomic fluorescence spectrometer AFS-920 equipped with a sequential injection HG sampling system (Beijing Titan Instrumentals Co. Ltd., Beijing, China) was used for Se measurement. The $\mathrm{Hg}$ sampling system provides high sensitivity and rapid isolation of Se from the mixture. A Se hollow cathode lamp was used as the radiation source at $196.0 \mathrm{~nm}$. The hydride was atomized with an argon-hydrogen flame. The operating parameters of the HG-AFS were optimized and are summarized in Table 2. Titan standard software was used for system control and data analysis.

Se concentration was expressed as milligram per kilogram dry weight. During the analysis, a reference substance (GSV-1 and GSV-3, Se concentration of $0.184 \pm 0.01$ and $0.140 \pm 0.01 \mathrm{mg} \mathrm{kg}^{-1}$, respectively), a blank, and duplicate samples (one duplicate per five samples) were used to ensure the accuracy and precision of the results (quality control). The measured values of GSV-1 and GSV-3 were $0.185 \pm 0.01(n=6)$ and $0.153 \pm 0.003 \mathrm{mg} \mathrm{kg}^{-1}$ $(n=4)$, respectively, which is consistent with the reference value. The blank was well below the detection limit $\left(0.2 \mu \mathrm{g} \mathrm{L}{ }^{-1}\right)$. The results of the duplicate samples were relatively good with a coefficient of variation $(\mathrm{CV})$ in the range of $1.3 \%$ to $6.0 \%$.

Statistical Analysis

JMP6.0 (SAS Institute) software was used to perform analysis of variance (ANOVA). Tukey-Kramer's honestly significant difference (HSD) test was used to compare means of all pairs (significance level, 5\%). Spearman's rho correlation was used to analyze the multivariate correlations.

\section{Results}

Natural Variation in H. spontaneum GSeC

Large variations were observed in $H$. spontaneum $\mathrm{GSeC}$ among the 92 genotypes and nine populations, respectively (Fig. 2 and Table 3). GSeC among the 92 genotypes ranged from 0 to $0.387 \mathrm{mg} \mathrm{kg}^{-1}$, with an average of $0.045 \mathrm{mg} \mathrm{kg}^{-1}$. The genotype with the highest GSeC was 20_C, which originated in the Sede Boqer population, while that with the lowest

Table 2 Operating Parameters of the Hydride Generation-Atomic Fluorescence Spectrometry

\begin{tabular}{ll}
\hline Parameters & Settings \\
\hline Selenium hollow cathode lamp & $196.0 \mathrm{~nm}$ \\
Lamp current & $75 \mathrm{~mA}$ \\
Negative high voltage of & $265 \mathrm{~V}$ \\
$\quad$ photomultiplier & \\
Atomizer height & $8 \mathrm{~mm}$ \\
Atomization temperature & $200^{\circ} \mathrm{C}$ \\
Carrier HCL flow & $0.72 \mathrm{~mol} / \mathrm{L}(6 \%)$ \\
KHB 4 concentration & $1 \%(w / v)($ in $0.2 \%(w / v) ~ \mathrm{NaOH}$ \\
& solution) \\
Carrier argon flow & $400 \mathrm{~mL} / \mathrm{min}$ \\
Shield argon flow & $800 \mathrm{~mL} / \mathrm{min}$ \\
\hline
\end{tabular}




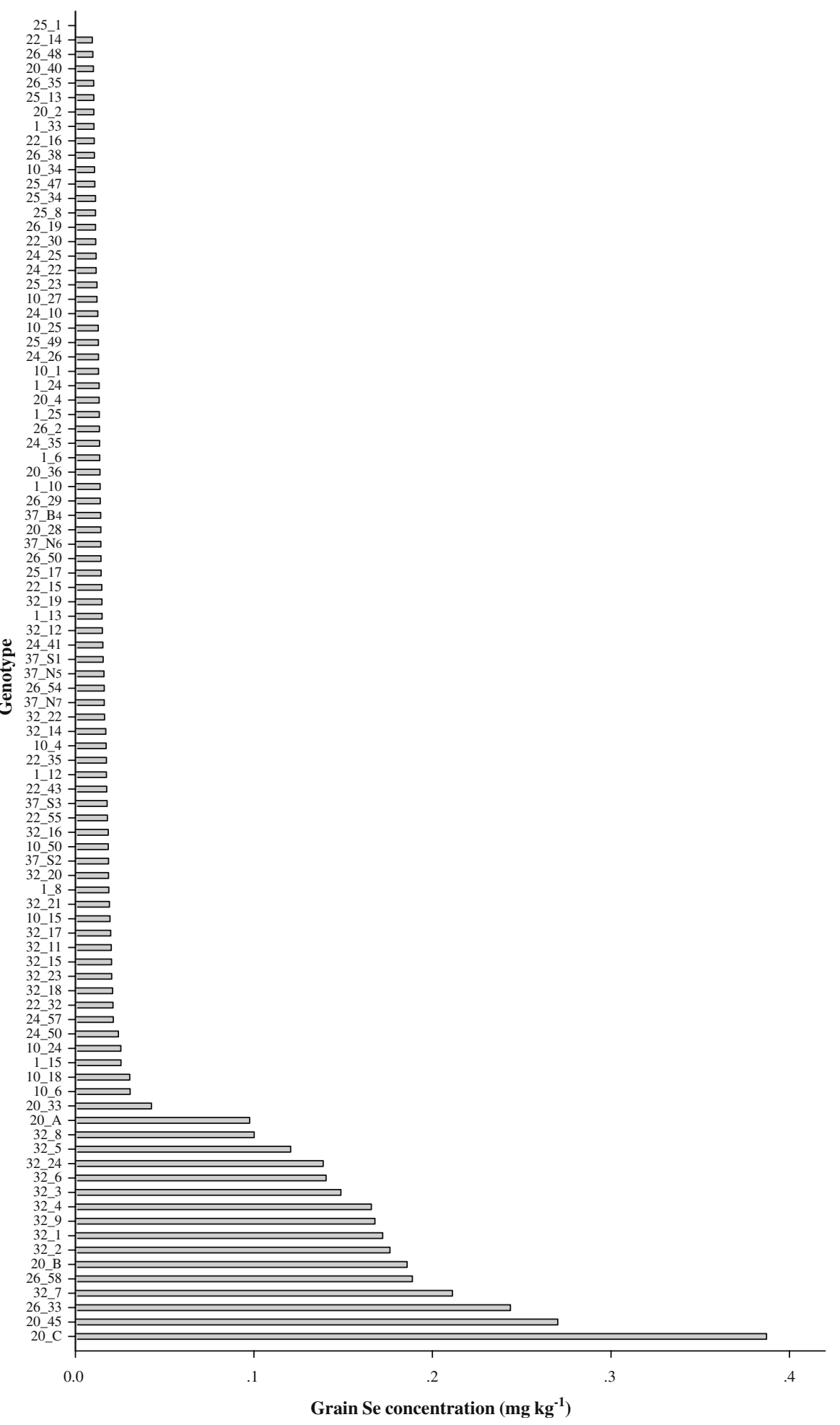


Fig. 2 GSeC of 92 Hordeum spontaneum genotypes

GSeC was 25 1, originating from the Atlit population. The mean value of $\mathrm{GSeC}$ in each population varied from 0.010 to $0.105 \mathrm{mg} \mathrm{kg}^{-1}$. GSeC of the Sede Boqer population, which ranged from 0.010 to $0.387 \mathrm{mg} \mathrm{kg}^{-1}$ and averaged $0.105 \mathrm{mg} \mathrm{kg}^{-1}$, ranked highest among the nine populations, while $\mathrm{GSeC}$ of the Atlit population, ranging from 0 to $0.014 \mathrm{mg} \mathrm{kg}^{-1}$ and averaging $0.010 \mathrm{mg} \mathrm{kg}^{-1}$, ranked the lowest. One-way ANOVA indicated significant differences in $\mathrm{GSeC}$ among the nine $H$. spontaneum populations $(P \leq 0.001)$. The population $\mathrm{CV}$ showed large differences among the nine populations, ranging from $12 \%$ for the "Evolution Canyon" population to $163 \%$ for the Caesarea population.

GSeC of Cultivated Barley as Compared with H. spontaneum

The GSeCs of the ten barley cultivars ranged from 0.000 to $0.144 \mathrm{mgkg}^{-1}$ (Table 3). Baoshan 8640-1 from Yunnan Province, Ganpi 3 from Gansu Province, and Yancheng 01094 and Supi 4 from Jiangsu Province had the lowest value of $0.000 \mathrm{mg} \mathrm{kg}^{-1}$, whereas Zhexiu 13 and Zhexiu 33 from Zhejiang Province had the highest values, 0.134 and $0.144 \mathrm{mg} \mathrm{kg}^{-1}$, respectively. However, the highest GSeC in a cultivar, that of cv. Zhexiu 33, was far lower than the highest GSeC in a wild barley genotype, that of 20_C $\left(0.387 \mathrm{mg} \mathrm{kg}^{-1}\right)$. A total of $11 \mathrm{H}$. spontaneum genotypes (three genotypes from Sede Boqer, six from Ein-Zukim, and two from Caesarea) had higher GSeCs than Zhexiu 33. The CV for the ten cultivars was $112 \%$, which was also lower than the highest CV (163\%)

Table 3 GSeC of Nine Hordeum spontaneum Populations and Ten Hordeum vulgare Cultivars

\begin{tabular}{|c|c|c|c|c|c|}
\hline ID & Populations/variety & Samples & $\mathrm{GSeC}\left(\operatorname{mean} \pm \mathrm{SD} ; \mathrm{m} \mathrm{kg}^{-1}\right)$ & Range $\left(\mathrm{mg} \mathrm{kg}^{-1}\right)$ & CV (\%) \\
\hline 1 & Mt. Hermon & 9 & $0.015 \pm 0.004$ & $0.010-0.026$ & 31 \\
\hline 10 & Maalot & 10 & $0.019 \pm 0.007$ & $0.011-0.131$ & 39 \\
\hline 20 & Sede Boqer & 10 & $0.105 \pm 0.133$ & $0.010-0.387$ & 128 \\
\hline 22 & Mehola & 8 & $0.015 \pm 0.004$ & $0.010-0.021$ & 27 \\
\hline 24 & Akhziv & 8 & $0.015 \pm 0.005$ & $0.012-0.024$ & 29 \\
\hline 25 & Atlit & 8 & $0.010 \pm 0.004$ & $0.000-0.014$ & 42 \\
\hline 26 & Caesarea & 10 & $0.053 \pm 0.087$ & $0.010-0.244$ & 163 \\
\hline 32 & Ein-Zukim & 22 & $0.080 \pm 0.072$ & $0.015-0.211$ & 90 \\
\hline \multirow[t]{2}{*}{37} & Evolution Canyon & 7 & $0.039 \pm 0.046$ & $0.014-0.123$ & 12 \\
\hline & Sum of Wild barley & 92 & $0.045 \pm 0.070$ & $0.000-0.387$ & $12-163$ \\
\hline $\mathrm{Zj} 1$ & Yunpi 2 & $1 \times 3$ & $0.028 \pm 0.003$ & & \\
\hline $\mathrm{Zj} 2$ & Yunpi 6 & $1 \times 3$ & $0.039 \pm 0.008$ & & \\
\hline $\mathrm{Zj} 3$ & Zhexiu 12 & $1 \times 3$ & $0.134 \pm 0.012$ & & \\
\hline $\mathrm{Zj} 4$ & E32380 & $1 \times 3$ & $0.073 \pm 0.013$ & & \\
\hline $\mathrm{Zj} 5$ & Yangnongpi 5 & $1 \times 3$ & $0.077 \pm 0.005$ & & \\
\hline Zj6 & Baoshan8640-1 & $1 \times 3$ & $0.000 \pm 0.000$ & & \\
\hline $\mathrm{Zj} 7$ & Yancheng 01094 & $1 \times 3$ & $0.000 \pm 0.000$ & & \\
\hline Zj8 & Zhexiu33 & $1 \times 3$ & $0.144 \pm 0.010$ & & \\
\hline Zj9 & Ganpi 3 & $1 \times 3$ & $0.000 \pm 0.000$ & & \\
\hline \multirow[t]{2}{*}{$\mathrm{Zj} 10$} & Supi 4 & $1 \times 3$ & $0.000 \pm 0.000$ & & \\
\hline & Sum of cultivars & $10 \times 3$ & $0.050 \pm 0.056$ & $0.000-0.144$ & 112 \\
\hline
\end{tabular}


in the Caesarea wild barley population. As expected, the cultivars exhibited a narrower GSeC range and less diversity than the wild barley.

\section{Association of H. spontaneum GSeC with Ecogeographical Factors}

Of the 14 correlations analyzed between $\mathrm{GSeC}$ and ecogeographical factors, 12 were statistically significant (Fig. 3). GSeC was negatively correlated with latitude, altitude, mean annual rainfall, mean number of rainy days, mean humidity at 1400 hours, and mean annual humidity and positively correlated with mean annual temperature, mean August temperature, mean January temperature, mean seasonal temperature difference, mean daily temperature difference, and mean annual evaporation, indicating that GSeC increased with temperature and evaporation and decreased with latitude, altitude, rainfall, and humidity, irrespective of longitude. Therefore, GSeC was mainly influenced by temperature and water conditions. One-way ANOVA showed that the mean GSeC of xeric genotypes was significantly greater than that of mesic genotypes $(P=0.0004)$.

Moreover, nine $H$. spontaneum populations were derived from five soil types (Table 4), and one-way ANOVA indicated a significant difference in GSeCs among the H. spontaneum originating from those five soil types $(P=0.0003)$. GSeC of $H$. spontaneum originated from loess was the highest, while that of $H$. spontaneum originated from alluvium was the lowest. Tukey-Kramer HSD test indicated that except for loess, the other four soil types - terra rosa, rendzina, alluvium, and sandy loam - gave similar GSeC values, and there was a significant difference in this parameter between loess and these other four soil types (Table 4).

Moreover, there were no significant correlations between GSeC and 1,000-grain weight for either wild $H$. spontaneum $(P=0.08)$ or barley cultivars $(P=0.41)$, indicating that higher $\mathrm{GSeC}$ is not necessarily related to small grain weight in barley.

\section{Discussion}

General Overview of Se in Food Plants

Se levels in food plants are generally low, with worldwide data on cereal and grain Se levels reporting $<0.1$ to $0.8 \mathrm{mg} \mathrm{kg}^{-1}$ [29]. However, cereals and their products make a major

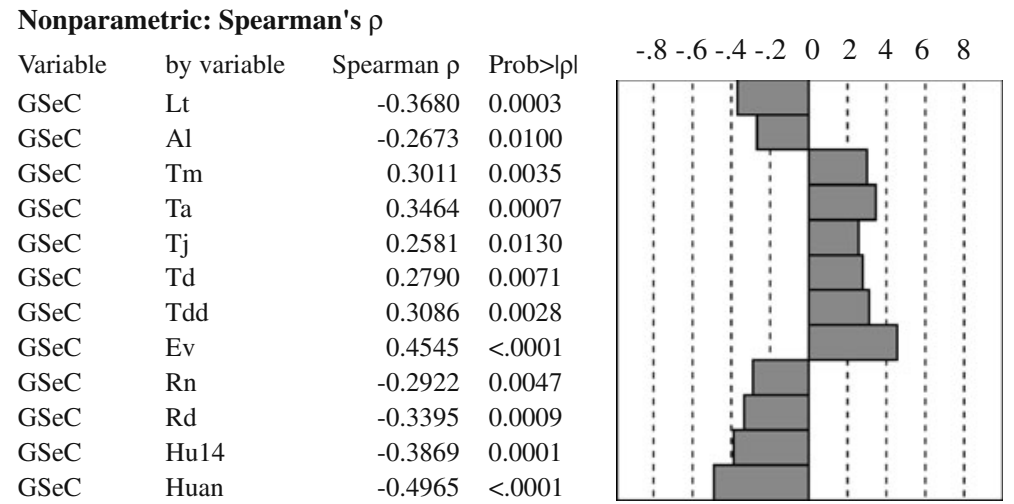

Fig. 3 Spearman's rho correlation between GSeC and ecogeographical data (Table 1) of the original sites of nine Hordeum spontaneum populations in Israel 
Table 4 GSeC of Hordeum spontaneum Originated From Five Different Soil Types in the Collection Site in Israel

\begin{tabular}{|c|c|c|c|c|c|c|}
\hline $\begin{array}{l}\text { Soil type (in the } \\
\text { collection site) }\end{array}$ & Samples & Population & $\begin{array}{l}\text { Mean } \pm \text { SD } \\
\left(\mathrm{mg} \mathrm{kg}^{-1}\right)\end{array}$ & $\begin{array}{l}\text { Range } \\
\left(\mathrm{mg} \mathrm{kg}^{-1}\right)\end{array}$ & CV (\%) & $\begin{array}{l}\text { Tukey-Kramer } \\
\text { HSD test, } P<0.05^{\mathrm{a}}\end{array}$ \\
\hline 1, Terra Rosa & 16 & $\begin{array}{l}\text { Mt. Hermon } \\
\text { Evolution Canyon }\end{array}$ & $0.016 \pm 0.004$ & $0.010-0.026$ & 23 & $\mathrm{~b}$ \\
\hline 2, Rendzina & 10 & Maalot & $0.019 \pm 0.007$ & $0.011-0.031$ & 39 & $\mathrm{~b}$ \\
\hline 3, Alluvium & 16 & $\begin{array}{l}\text { Mehola } \\
\text { Akhziv }\end{array}$ & $0.015 \pm 0.004$ & $0.010-0.024$ & 27 & $\mathrm{~b}$ \\
\hline 4, Sandy loam & 18 & $\begin{array}{l}\text { Atlit } \\
\text { Caesarea }\end{array}$ & $0.034 \pm 0.067$ & $0.000-0.244$ & 196 & $\mathrm{~b}$ \\
\hline 6, Loess & 32 & $\begin{array}{l}\text { Sede Boqer } \\
\text { Ein-Zukim }\end{array}$ & $0.088 \pm 0.094$ & $0.010-0.387$ & 107 & $\mathrm{a}$ \\
\hline ANOVA & & & $P \leq 0.001$ & & & \\
\hline
\end{tabular}

${ }^{\text {a }}$ Different letters stand for significant differences among soil types

contribution to the dietary intake of $\mathrm{Se}$ in the population worldwide, especially in developing countries such as China and India [11]. The World Health Organization and Food and Agriculture Organization normative requirement estimates of dietary Se are 0.04 and $0.03 \mathrm{mg}$ day $^{-1}$ for men and women, respectively [30]. The US, Canadian, and European recommended dietary allowance (RDA) for Se is $0.055 \mathrm{mg} \mathrm{day}^{-1}[31,32]$. In

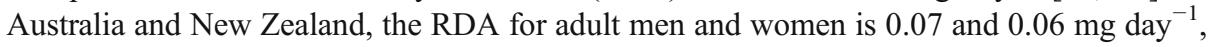
respectively [33]. In the $U K$, the reference nutrient intake is set at 0.075 and $0.060 \mathrm{mg} \mathrm{day}^{-1}$ for adult males and females, respectively [34]. In many countries, rice and wheat are the most commonly consumed cereals. Nevertheless, Se levels in rice and wheat sold for domestic consumption are insufficient in some countries, for example, a mean Se level in rice of $0.05 \mathrm{mg} \mathrm{kg}^{-1}$ in Thailand and $0.02 \mathrm{mg} \mathrm{kg}^{-1}$ in China [2]. British wheat has low Se status [35], with Se levels in bread being approximately 0.039 to $0.048 \mathrm{mg} \mathrm{kg}^{-1}$ [2]. The average wheat $\mathrm{GSeC}$ in Scandinavian countries ranges from 0.007 to $0.018 \mathrm{mg} \mathrm{kg}^{-1}$ [36]. Aro et al. [37] reported mean wheat GSeCs of $0.001,0.005$, and $0.028 \mathrm{mg} \mathrm{kg}^{-1}$, respectively, in three studied villages of Transbaikalian Russia. Most of the world's wheat falls within the ca. 0.002 to $0.060 \mathrm{mg} \mathrm{kg}^{-1}$ range [38]. Consequently, Se malnutrition afflicts quite a few people, especially those living in areas of very low Se availability in soils and extremely low Se concentrations in staple crops [4, 8]. On the other hand, the bioavailability of organic Se in plant and animal sources is higher than that of the inorganic selenate and selenite [31]. Moreover, Se in wheat grain is highly bioavailable compared to some fish and vegetables [32, 39, 40], and wheat is the most efficient Se accumulator of the common cereal crops [5]. Therefore, in recent years, researchers have focused on strategies to exploit genetic resources and develop genetically Se-enriched and protein-Se-enriched wheat using genomics tools [5, 6, 15, 31, 41-44].

\section{Se in Barley}

Surprisingly, reports on GSeC in barley have been scant in recent years. Barley is one of the principal cereal crops, the fourth largest in the world. It serves as a major animal feed crop and as human food it is used for malting, which in turn is used to make beer, whisky, and several other products such as bread, biscuits, and soups. In Chinese Tibet, barley was 
grown mostly as a staple food for humans. Recently, however, interest in barley as a food grain is reviving due to heightened consumer awareness of good nutrition and increased interest in foods and food ingredients that are enriched in dietary fiber [45].

Barley is not only an economically important crop but it is also considered as a model species for genetic studies [46, 47]. Wild barley, as the progenitor of cultivated barley, is an important genetic resource that can be exploited in breeding programs for the introduction of resistance to a broad range of diseases and pests, tolerance to drought, salt, poor soils and climate factors, and key properties, e.g., malting content, kernel weight, size, color, and dormancy [22, 23, 4852]. In the current study, a wide range and very high GSeCs were found in 92 genotypes of $H$. spontaneum from nine populations. GSeCs of $11 \mathrm{H}$. spontaneum genotypes were higher than that of the highest cultivar (Zhexiu 33) out of ten Chinese cultivars. The genotype of $H$. spontaneum with the highest GSeC (20_C) had 2.7 times the GSeC of cv. Zhexiu 33 (Table 3 and Fig. 2). Furthermore, in the current set of experiments, the grains were harvested from plants that had been grown in the same location, at the same time, under the same conditions. Therefore, the variation in $\mathrm{GSeC}$ revealed genetic differences resulting from the adaptation of $H$. spontaneum to different eco-environments. Our results demonstrate the huge potential of wild barley for improvement of GSeC. These high-GSeC H. spontaneum genotypes can be utilized as a set of donor parents for biofortification of barley cultivars and as optimized model plants for the improvement of cereal Se concentration via gene introgression, towards the development of Se-enriched cereals in the future.

The environment is a key contributor to the range of morphological variation found in various organisms [53]. Associations between the performance of wild barley populations and the ecogeographical conditions of their collection sites can shed light on the major driving forces contributing to the ecological fitness of these populations and, more specifically, to the development of their Se uptake and accumulation mechanisms. In the current study, Spearman correlation analysis showed that high temperature and evaporation and low latitude, altitude, rainfall, and humidity at the site in which $H$. spontaneum originated are favorable to wild barley having gained a strong ability to take up Se from the soil and to accumulate Se in its grains during evolution. This could explain why the Sede Boqer and Ein-Zukim populations, which originated in sites with the lowest latitude, altitude, and rainfall and highest temperature and evaporation, had the highest GSeCs, while the Mt. Hermon population, originating in the site with the lowest temperature and highest latitude, altitude, and rainfall, was ranked second lowest in GSeC of the nine populations. Soil type at the $H$. spontaneum collection site was also an important factor affecting its ability to take up Se and to accumulate Se in its grains. The report drew particular attention to the wide range of Se concentrations in different types of foods and revealed that the variations are due to differences in Se availability in the soil on which an animal is raised or a plant grown [2]. In the present study, nine H. spontaneum populations were derived from five soil types. GSeC of $H$. spontaneum originating from loess soil was highest and significantly higher than the $\mathrm{GSeC}$ in $H$. spontaneum originating from alluvium (lowest), terra rosa, rendzina, and sandy loam (Table 4). Our results suggest that loess has low Se availability and that the wild barley growing there has developed strong Se uptake and accumulation abilities. Se occurs in well-drained alkaline soils chiefly as selenates, which are highly available for absorption by plant roots. In contrast, in acidic, poorly drained soils, it is present mainly as selenides, which are not available to plants, and sometimes as elemental Se [54]. In reality, the loess soil in both Sede Boqer and Ein-Zukim was not true loess, but a desert soil which was very poorly drained. However, to support this hypothesis, additional studies are required to determine soil Se content and availability in the original sites from which the $H$. spontaneum populations were collected. 
All of the results of this study clearly demonstrate that the evolutionary background of the environments has a strong effect on GSeC of wild barley. H. spontaneum is hermaphroditic and self-pollinating [55], with a fragile rachis that breaks apart after maturation [56], such that the spikelets become entangled in the remains of their dry mother plants, contributing to the development of local genotypes. The great biodiversity found among these genotypes is the result of adaptations to local environmental factors in each area and microhabitat. These factors include the amount of rain, temperature, type and depth of soil, slope direction, shade, presence of stones, rocks, salinity, and possibly also other factors [57]. A particular food may show an over tenfold difference in Se content, depending on where it was produced. Se levels in foods can vary enormously, not only between countries but also between regions within a country [2]. Stochastic environmental fluctuations create a mosaic of habitats in which variation takes place in a temporal rather than spatial dimension [58]. Therefore, the genetic population structure of barley is a mosaic. In the present study, though the Caesarea population originated in a mesic habitat, it ranked third out of nine populations in $\mathrm{GSeC}$. The Mehola population, originating in a xeric habitat, ranked second lowest in GSeC. Our results indicate that large differences exist between and within populations. The $\mathrm{CV}$ of each of the nine populations ranged from $12 \%$ to $163 \%$. In the Sede Boqer population, the CV was large (128\%), and the GSeC of the highest genotype 20_C was 38.7 times higher than that of genotype 20_40. Thus, the genetic mosaic appears to reflect the underlying ecological heterogeneity, which derives from local and regional geological, edaphic, climatic, and biotic differentiations [59]. The genetic mosaicism of wild barley GSeCs is the basis of barley GSeC improvement. The high-GSeC genotypes selected in the present study will be used to breed for barley cultivars with high GSeC. Cultivated barley contains, on average, 40\% H. spontaneum alleles [60]. Because $H$. spontaneum and cultivated barley are inter-fertile, $H$. spontaneum can be used to increase the genetic diversity of cultivated barley by crosses [61]. In the past, breeders were reluctant to use exotic germplasm in their breeding programs due to linkage drag of negative traits. However, modern genomic technologies have led to the development of marker-assisted selection (MAS) approaches that enable efficient transfer of only small chromosome segments carrying the target gene and therefore avoiding linkage drag of negative traits. For example, the stripe rust resistance gene $\mathrm{Yr} 15$, derived from wild emmer wheat, is being utilized in MAS wheat breeding programs in the USA (http://maswheat.ucdavis.edu/Index.htm). A few years ago, the high grain protein and mineral gene, Gpc-B1 (TtNAM-B1), was cloned from wild emmer wheat [14]. The absence of the functional TtNAM-B1 wild emmer allele in modern germplasm suggests a broad potential impact of this gene in breeding of cultivated wheat varieties [14]. Moreover, a homologous barley gene, designated $H v N A M-1$ was shown to be responsible for the grain protein QTL located on barley chromosome 6H [62]. Therefore, the results presented in the current and previous studies demonstrate the potential of wild cereal populations as a rich source for grain protein and mineral content genes for crop improvement.

Acknowledgements This study was funded by the Training Program Foundation for the Youth Talents in Science and Technology by Guizhou Province in China (2007-2010). The authors are greatly indebted to Lingling Zhang, Zhouyun Pan, Xiuwen Wei, Mingliang Hu, Junbo Gou, Changmin Xu, Yunchang Wang, and Bin Wan at Guizhou University in China for their excellent help in fieldwork. The authors also wish to express their thanks to the State Key Laboratory of Environmental Geochemistry, Institute of Geochemistry, Chinese Academy of Sciences and Hangzhou National Barley Improvement Center, China. E. N. thanks the Ancell-Teicher Research Foundation for Genetics and Molecular Evolution for financial support. 
Open Access This article is distributed under the terms of the Creative Commons Attribution Noncommercial License which permits any noncommercial use, distribution, and reproduction in any medium, provided the original author(s) and source are credited.

\section{References}

1. Rayman MP (2000) The importance of selenium to human health. Lancet 356(9225):233-241

2. Reilly C (2006) Selenium in food and health, 2nd edn. Springer, New York, p p198

3. Seboussi R, Faye B, Alhadrami G et al (2010) Selenium distribution in camel blood and organs after different level of dietary selenium supplementation. Biol Trace Elem Res 133:34-50

4. Combs GF (2001) Selenium in global food systems. Br J Nutr 85:517-547

5. Lyons GH, Stangoulis JCR, Graham RD (2003) High-selenium wheat: biofortification for better health. Nutr Res Rev 16:45-60

6. Lyons GH (2010) Selenium in cereals - improving the efficiency of agronomic. Plant Soil 332:1-4

7. Combs GF (1988) Selenium in foods. In: Chichester CO, Schweiger BS (eds) Advances in Food Research. Academic, San Diego, pp 85-113

8. Bugel S, Sandstrom B, Larsen EH, Skibsted LH (2002) Is selenium from animal sources bioavailable? Eleventh Symposium on Trace Elements in Man and Animals, 2-6 June 2002, Trace Elements in Man and Animals Committee, Berkeley

9. Yang X, Tian Y, Ha P, Gu L (1997) Determination of the selenomethionine content in grain and in human blood. Wei Sheng Yen Chiku (J Hyg Res) 26:113-116

10. Schrauzer GN (2001) Nutritional selenium supplements: product types, quality and safety. J Am Coll Nutr 20:1-4

11. FAO/WHO (2001) Human vitamin and mineral requirements. Report of a Joint FAO/WHO Expert Consultation, Bangkok, Thailand. Food and Nutrition Division, FAO, Rome

12. Cakmak I (2008) Enrichment of cereal grains with zinc: agronomic or genetic biofortification? Plant Soil 302:1-17

13. Fordyce FM (2005) Selenium deficiency and toxicity in the environment. In: Selinus O, Alloway B, Centeno JA, Finkelman RB, Fuge R, Lindh U, Smedley P (eds) Essentials of medical geology. Elsevier, London, pp 373-415

14. Uauy C, Distelfeld A, Fahima T et al (2006) A NAC gene regulating senescence improves grain protein, zinc, and iron content in wheat. Science 314:1299-1301

15. Bouis HE (2003) Micronutrient fortification of plants through plant breeding: can it improve nutrition in man at low cost? Proc Nutr Soc 62:403-411

16. Ghandilyan A, Vreugdenhil D, Aarts MGM (2006) Progress in the genetic understanding of plant iron and zinc nutrition. Physiol Plant 126:407-417

17. Welch RM, Graham RD (2004) Breeding for micronutrients in staple food crops from a human nutrition perspective. J Exp Bot 55:353-364

18. Nevo E (1992) Origin, evolution, population genetics and resources for breeding of wild barley, Hordeum spontaneum, in the Fertile Crescent. In: Shewry P (ed) Barley: genetics, molecular biology and biotechnology. C.A.B. International, Wallingford, pp 19-43

19. Zohary D (1969) The progenitors of wheat and barley in relation to domestication and agricultural dispersal in the old world. In: Ucko PJ, Dimbelby GW (eds) Domestication and exploitation of plants and animals. Gerald Duckworth, London, pp 47-66

20. Zohary D, Hopf M (1988) Domestication of plants in the old world. Clarendon, Oxford

21. Nevo E, Beiles A, Gutterman Y et al (1984) Genetic resources of wild cereals in Israel and the vicinity: II. Phenotypic variation within and between populations of wild barley, Hordeum spontaneum. Euphytica 33:737-756

22. Nevo E, Beiles A, Zohary D (1986) Genetic resources of wild barley in the near East: structure, evolution and application in breeding. Biol J Linn Soc 27(4):355-380

23. Nevo E, Apelbaum-Elkaher I, Garty J et al (1997) Natural selection causes microscale allozyme diversity in wild barley and a lichen at "Evolution Canyon" Mt. Carmel, Israel. Heredity 78:373-382

24. Nevo E, Korol AB, Beiles A et al (2002) Evolution of wild emmer and wheat improvement-population genetics, genetic resources, and genome organization of wheat's progenitor, Triticum dicoccoides. Springer, Berlin

25. Nevo E (1986) Genetic resources of wild cereals and crop improvement: Israel, a natural laboratory. Isr J Botan 35:255-278 
26. Nevo E (2004) Population genetic structure of cereal wild progenitors. In: Gupta PK, Varshney RK (eds) Cereal genomics. Kluwer Academic Press, Dordrecht, pp 135-163

27. Brantestam AK (2005) A century of breeding - is genetic erosion a reality? Temporal diversity changes in Nordic and Baltic barley. Ph.D. Thesis submitted to Swedish University of Agricultural Sciences, Alnarp

28. Zhu JM, Li L, Qin HB et al (2008) Determination of total selemium in environmental samples by hydride generation-atomic fluorescence spectrometry with PTFE bomb. Actamneral Sin 28(2):880-981, in Chinese

29. World Health Organization (1987) Selenium. A Report of the International Programme on Chemical Safety. Environmental Health Criteria 58, World Health Organization, Geneva

30. WHO/FAO/IAEA (1996) Trace elements in human nutrition and health. World Health Organization, Geneva

31. Hawkesford MJ, Zhao FJ (2007) Strategies for increasing the selenium content of wheat. J Cereal Sci 46 (3):282-292

32. Thomson CD (2004) Assessment of requirements for selenium and adequacy of selenium status: a review. Eur J Clin Nutr 58:391-402

33. National Health and Medical Research Council (2005) Nutrient reference values for Australia and New Zealand including recommended dietary intakes. Commonwealth of Australia, Canberra, p 316

34. Department of Health (1991) Dietary reference values for food energy and nutrients for the United Kingdom. Report on Health and Social Subjects, No. 41, Her Majesty's Stationery Office, London

35. Barclay MNI, Macpherson A (1986) Selenium content of wheat flour used in the UK. J Sci Food Agric 37:1133-1138

36. Gissel-Nielsen G, Gupta UC, Lamand M et al (1984) Selenium in soils and plants and its importance in livestock and human nutrition. Adv Agron 37:397-460

37. Aro A, Kumpulainen J, Alfthan G et al (1994) Factors affecting the selenium intake of people in Transbaikalian Russia. Biol Trace Elem Res 40:277-285

38. Alfthan G, Neve J (1996) Selenium intakes and plasma selenium levels in various populations. In: Kumpulainen J, Salonen J (eds) Natural antioxidants and food quality in atherosclerosis and cancer prevention. Royal Society of Chemistry, Cambridge, pp 161-167

39. Meltzer HM, Bibow K, Paulsen IT et al (1993) Different bioavailability in humans of wheat and fish selenium as measured by blood platelet response to increased dietary Se. Biol Trace Elem Res 36:229-241

40. Fox TE, Atherton C, Dainty JR et al (2005) Absorption of selenium from wheat, garlic, and cod intrinsically labeled with Se-77 and Se-82 stable isotopes. Int J Vitam Nutr Res 75:179-186

41. Lyons GH, Ortiz-Monasterio I, Stangoulis JCR et al (2005) Selenium concentration in wheat grain: is there sufficient genotypic variation to use in breeding? Plant Soil 269:369-380

42. Lyons GH, Genc Y, Stangoulis JCR et al (2005) Selenium distribution in wheat grain, and the effect of postharvest processing on wheat selenium content. Biol Trace Elem Res 103:155-168

43. Lyons GH, Judson GJ, Ortiz-Monasterio I et al (2005) Selenium in Australia: selenium status and biofortification of wheat for better health. J Trace Elem Med Biol 19:75-82

44. Zhang CX, Yan J, Cheng JP et al (2009) Variance analysis of grain selenium density in wild emmer wheat, Triticum dicoccoide. J Trop Subtrop Bot 17(3):229-236, in Chinese

45. Izydorczyk MS, Dexter JE (2008) Barley $\beta$-glucans and arabinoxylans: molecular structure, physicochemical properties, and uses in food products: a review. Food Res Int 41:850-868

46. Koornneef M, Alonso-blanco C, Peeters AJM (1997) Genetic approaches in plant physiology. New Phytol 137:1-8

47. Schulte D, Close TJ, Graner A et al (2009) The international barley sequencing consortium-at the threshold of efficient access to the barley genome. Plant Physiol 149:142-147

48. Chen G, Suprunova T, Krugman T et al (2004) Ecogeographic and genetic determinants of kernel weight and colour of wild barley (Hordeum spontaneum) populations in Israel. Seed Sci Res 14:137-146

49. Chen G, Komatsuda T, Pourkheirandish M et al (2009) Mapping of the eibil gene responsible for the drought hypersensitive cuticle in wild barley (Hordeum spontaneum). Breed Sci 59:21-26

50. Chen G, Krugman T, Fahima $\mathrm{T}$ et al (2010) Chromosomal regions controlling seedling drought resistance in Israeli wild barley, Hordeum spontaneum C. Koch. Genet Resour Crop Evol 57:85-99

51. Zhang F, Chen G, Huang Q et al (2005) Genetic basis of barley caryopsis dormancy and seedling desiccation tolerance at the germination stage. Theor Appl Genet 110:445-453

52. Yan J, Chen GX, Cheng JP et al (2008) Phenological and phenotypic differences and correlations among genotypes of Hordeum spontaneum originating from different locations in Israel. Genet Resour Crop Evol 55(7):995-1005

53. van Valen L (1965) Morphological variation and width of ecological niche. Am Nat 99:377-390

54. National Research Council (1971) Selenium in nutrition. National Academy Press, Washington

55. Brown A, Zohary D, Nevo E (1978) Association of alleles at esterase loci in wild barley Hordeum spontaneum L. Nature 268:430-431 
56. Feinbrun-Dothan N (1986) Flora Palestina, Part Four-Text. Israel Acad Sciences and Humanities, Jerusalem

57. Gutterman Y (2002) Survival strategies of annual desert plants. Adaptations of desert organisms. Springer, Berlin, $348 \mathrm{pp}$

58. Peleg Z, Saranga Y, Krugman T et al (2008) Allelic diversity associated with aridity gradient in wild emmer wheat populations. Plant Cell Environ 31:39-49

59. Nevo E, Beiles A (1989) Genetic diversity of wild emmer wheat in Israel and Turkey. Theor Appl Genet 77:421-455

60. Ellis R, Foster B, Handley L et al (2000) Wild barley: a source of genes for crop improvement in the 21st century? J Exp Bot 51:9-17

61. Nevo E, Chen GX (2010) Drought and salt tolerances in wild relatives for wheat and barley improvement. Plant Cell Environ 33:670-685

62. Distelfeld A, Korol AB, Dubcovsky J et al (2008) Colinearity between the barley grain protein content (GPC) QTL on chromosome arm 6HS and the wheat Gpc-B1 region. Mol Breed 22:25-38

63. Dawson IK, Chalmers KJ, Waugh R et al (1993) Detection and analysis of genetic variation in Hordeum spontaneum populations from Israel using RAPD markers. Mol Ecol 2:151-159 